Table 1. CONCeNtration OF MUCOPOLYSACCHARIDES IN THE SKIN OF NORMAL ADULT RATS

\begin{tabular}{|c|c|c|c|c|}
\hline $\begin{array}{l}\text { Animal } \\
\text { (Exp. No. } \\
\text { and sex) }\end{array}$ & $\begin{array}{c}\text { Total conc. of } \\
\text { mucopolysaccharides } \\
\text { ( } \mu \text { mg uronic } \\
\text { acid/g dry skin) }\end{array}$ & $\begin{array}{c}\text { Hyaluronic } \\
\text { acid } \\
\%\end{array}$ & $\begin{array}{l}\text { Chondroitin } \\
\text { sulphate } \\
\text { f total uronic }\end{array}$ & $\underset{\text { id }}{\text { Heparin }}$ \\
\hline $\begin{array}{ll}1 & 0 \\
2 & 0 \\
3 & 0 \\
3\end{array}$ & $\begin{array}{r}790 \\
960 \\
1,140\end{array}$ & $\overline{75}$ & $\overline{10}$ & $\underline{15}$ \\
\hline 40 & 1,080 & 57 & 19 & 24 \\
\hline 5 9 & 1,090 & 65 & 17 & 18 \\
\hline $\begin{array}{ll}6 & 0 \\
7 & 9 \\
9\end{array}$ & $\begin{array}{l}1,010 \\
1,100\end{array}$ & 65 & $\begin{array}{l}22 \\
14\end{array}$ & 13 \\
\hline 89 & 1,030 & 51 & 15 & 34 \\
\hline 9 웅 & 930 & 59 & 30 & 11 \\
\hline 10 & - & 68 & 16 & 16 \\
\hline $\begin{array}{l}\text { Average } \\
\text { * S.D. }\end{array}$ & $1,015 \pm 108^{*}$ & $63 \pm 8$ & $18 \pm 6$ & $19 \pm 8$ \\
\hline
\end{tabular}

Table 2. Concentration of Mucopolysaccharides in the SkIN Of DULT HYPOPHYSECTOMOZED RATS

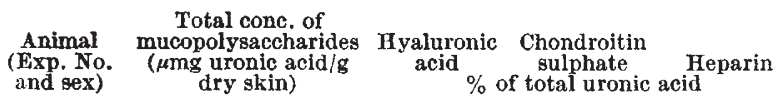

\begin{tabular}{|c|c|c|c|c|}
\hline $\begin{array}{cc}11 & 0 \\
12 & 0 \\
13 & 0 \\
14 & 0 \\
15 & 0 \\
16 & 9 \\
17 & 9 \\
18 & 9 \\
19 & 9 \\
20 & 9 \\
21 & 9 \\
\text { Average }\end{array}$ & $\begin{array}{r}900 \\
750 \\
1,000 \\
920 \\
1,010 \\
-930 \\
800 \\
1,060 \\
1,060 \\
870 \\
930 \pm 95\end{array}$ & $\begin{array}{c}69 \\
68 \\
55 \\
59 \\
57 \\
42 \\
63 \\
52 \\
74 \\
56 \\
55 \\
59 \pm 9\end{array}$ & $\begin{array}{c}18 \\
17 \\
20 \\
20 \\
23 \\
35 \\
26 \\
36 \\
12 \\
33 \\
34 \\
25 \pm 8\end{array}$ & $\begin{array}{r}13 \\
15 \\
25 \\
21 \\
20 \\
23 \\
11 \\
12 \\
14 \\
11 \\
11 \\
16 \pm 5\end{array}$ \\
\hline
\end{tabular}
Values for pooled sample from
840

were about 3 to 5 months of age. Schiller and Dorfman ${ }^{10}$ found the concentration of hyaluronic acid and chondroitin sulphate in the skin of 44-day-old rats to be much greater than that of mature rats.

The results of the present work suggest that the in vivo 'permeability' changes of dermal connective tissue which follow the ablation of the pituitary may not be a result of a change in the concentration of mucopolysaccharides, but could possibly result from a decrease in the degree of polymerization of the hyaluronic acid or other mucopolysaccharides as suggested earlier ${ }^{6}$

In conclusion, the present findings show that hypophysoctomy does not affect the mucopolysaccharide content of skin, at least not in adult rats. The concentrations of the different mucopolysaccharides are not affected oven 2 months after the hypophysectomy.

This work was supported by the National Institute of Arthritis and Metabolic Diseases, U.S. Public Health Service, grant $A-4619$.

Go Matsumura JoHN FABIANEK * ANTHONY HERP Ward Pigman

Department of Biochemistry,

New York Modical College,

Now York 29

New York.

* Research Fellow of The John Polachek Foundation.

${ }^{1}$ Fabianek, J., Herp, A., Dau, P., and Pigman, W., Abst. Eighth Interim Sci. Session Amer. Rhum. Assoc., Washington, D.C., 11 (Dec. 8-9, 1961).

2 Fabianek, J., Herp, A., Calick, A., and Pigman, W., Fed. Proc., 22, 437 (1963).

${ }^{3}$ Pigman, W., Bull. Soc. Chim. Biol., 45, 185 (1963).

- Fabianek, J., Herp, A., and Pigman, W., Arch. Intern. Physiol. Biochim. (in the press).

${ }^{5}$ Fabianek, J., et al. (submitted for publication).

- Fabianek, J., et al. (submitted for publication).

'See for the composition of this diet: Fabianek, J., and Appleton, A. (submitted for publication)

${ }^{8}$ Schiller, S., Slover, G. A., and Dorfman, A., J. Biol. Chem., 236, 983 (1961).

- Dische, Z., J. Biol. Chem., 16\%, 189 (1947).

${ }^{10}$ Schiller, S., and Dorfman, A., Nature, 185, 111 (1960)

1 Schiller, S., and Dorfman, A., Fed. Proc., 16, 242 (1957).

'schiller, S., J. Chron. Dis., 16, 291 (1963).

\section{Effect of Propanol-Water Mixtures on the Reactivity of Wool Cystine}

ThIs communication shows that the concept of hydrophobic bonds in interactions of soluble proteins ${ }^{1}$ can also be applied to water-insoluble fibrous proteins. It has been observed ${ }^{2,3}$ that lanthionine formation in wool at $65^{\circ} \mathrm{C}$ with sodium hydrogen carbonate or borate is much faster in mixed solvents than in aqueous solutions. This effect was not explained by the authors. It was also found by Atkinson, Filson and Speakman ${ }^{4,5}$ that it is more difficult to extend wool fibres in water alone than in saturated aqueous butanol. Now there is evidence that addition of organic solvents will tend to overcome the resistance of the hydrophobic interior of proteins to penetration by the aqueous solvent and thus may increase the reactivity of protein groups located in hydrophobic regions.

New experiments (Fig. 1) on the relationship of propanol concentration to the wool cystine degradation by $0 \cdot 1$ normal sodium carbonate at $45^{\circ} \mathrm{C}$ gave a maximum cystine reactivity in 60 per cent $(\mathrm{v} / \mathrm{v})$ aqueous propanol. In Fig. 1 the results given in ref. 3 for the same solvent are included to show the close similarity of the solvent effect.

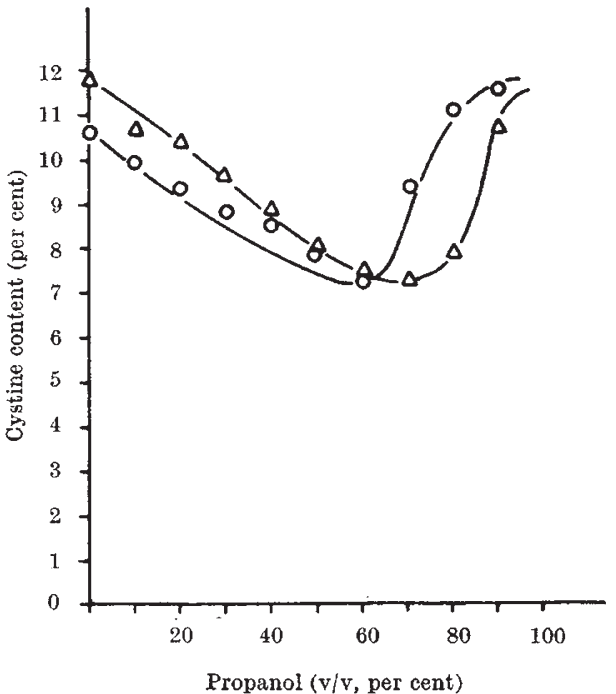

Fig. 1. Change in the cystine content in merino wool in 0.1 normal $65^{\circ} \mathrm{C} .4 \mathrm{~h}(\triangle)$ as a function of the concentration of propanol

The results suggest that the increased reactivity of wool cystine bonds in 10-80 per cent $(\mathrm{v} / \mathrm{v})$ aqueous propanol is best described as the consequence of a non-specific interaction of the solvent with the wool protein, resulting in the weakening of the hydrophobic interactions and the consequent exposure of wool cystine groups to the action of alkali.

Note added in proof. J. A. MacLaren (Austral. J. Chem.. $15,824 ; 1962)$ also regards wool as a protein linked by hydrophobic as well as hydrophilic interactions and found the extent of reduction of wool by thiols in aqueous alcohols increased.

\section{H. Z $\mathrm{AHN}$}

T. Gerthsen

Deutsches Wollforschungsinstitut an der

Technischen Hochschule, Aachen.

${ }^{1}$ Kauzmann, W., Adv. Protein Chem., 14, 1 (1959).

${ }^{2}$ Zahn, H., and Osterloh, F., Makromol. Chem., 16, 183 (1955).

${ }^{3}$ Zahn, H., and Wiedersich I., Deutsches Bundespatent, No, 1041216 (1.8.1955).

4Filson, A., and Speakman, J. B., J. Soc, Dyers, Col, 74, 762 (1958).

${ }^{5}$ Atkinson, J. C., Filson, A., and Speakman, J. B., Nature, 184, 444 (1959). 